\title{
Multicuspidate shark teeth associated with chondrichthyan and acanthodian scales from the Emsian (Devonian) of southern Algeria
}

\author{
Claire DERYCKE \\ Université de Lille 1, Laboratoire Géosystèmes, \\ UMR 8157 CNRS, Bâtiment Sciences de la Terre SN5, \\ F-59655 Villeneuve d'Ascq cedex (France) \\ and UMR 7207 du CNRS, \\ Muséum national d'Histoire naturelle, \\ case postale 38, 57 rue Cuvier, F-75231 Paris cedex 05 (France) \\ claire.derycke@univ-lille1.fr \\ Daniel GOUJET \\ UMR 7207 CNRS, Muséum national d'Histoire naturelle, \\ case postale 38, 57 rue Cuvier, F-75231 Paris cedex 05 (France) \\ goujet@mnhn.fr
}

KEY WORDS

Chondrichthyes,

Acanthodii,

teeth, scales,

Devonian,

Algeria,

south Ahaggar,

new species,

new genus.

MOTS CLÉS Chondrichthyes,

Acanthodii, dents,

écailles,

Algérie,

sud Hoggar,

espèce nouvelle, genre nouveau.
Derycke C. \& Goujet D. 2011. - Multicuspidate shark teeth associated with chondrichthyan and acanthodian scales from the Emsian (Devonian) of southern Algeria. Geodiversitas 33 (2): 209-226. DOI: 10.5252/g2011n2a1.

\section{ABSTRACT}

Previously undescribed Emsian vertebrates from southern Algeria (southern Ahaggar) include a new chondrichthyan Tassiliodus lessardi n. gen., n. sp. with multicuspidate teeth and scales with a distinctive histology. This is the first Emsian chondrichthyan taxon reported from the north-western margin of Gondwana. Rare acanthodian scales are assigned to Milesacanthus cf. ancestralis Burrow, Lelièvre \& Janjou, 2006, an Emsian species also known from Saudi Arabia, reinforcing the Gondwanan faunal affinity.

\section{RÉSUMÉ}

Dents multicuspides de requin associées à des écailles de Chondrichthyen et d'Acanthodien de l'Emsien (Dévonien) du sud de l'Algérie.

Du matériel inédit de vertébrés provenant du sud Hoggar (sud Algérie) comprend deux dents multicuspides d'un nouveau Chondrichthyen, Tassiliodus lessardi n. gen., n. sp. accompagnées d'écailles présentant un nouveau dispositif histologique. Il s'agit du premier enregistrement de Chondrichthyens d'âge Emsien sur la marge Nord-Ouest Gondwana. Quelques écailles de Milesacanthus cf. ancestralis Burrow, Lelièvre \& Janjou, 2006 (Acanthodien), décrites auparavant dans l'Emsien d'Arabie Saoudite, renforcent les affinités gondwaniennes du matériel. 


\section{INTRODUCTION}

Palaeozoic early vertebrate remains from Algeria are sparse, and generally only briefly mentioned in the current literature. A Silurian calcareous level from Ougarta (Fig. 1 [1]) (Oued Ali) yielded remains of armoured "agnathans" (Massa et al. 1965 in Fabre 1976: 107; Fabre 2005: 214) also reported by Nedjari et al. (2007: 37). Blieck (1982) recorded the only putative, but doubtful, heterostracan of Africa from the Pridoli of Ougarta. Acanthodian scales have also been reported from the Siluro-Devonian boundary of southern Algeria (Ougarta, Oued Ali section) (Blieck et al. 1984).

Devonian remains are more abundant. The Devonian fish faunal list for Algeria mentioned some Lower Devonian shark scales in the Idekel sandstone (Edikel sandstone, southern Algeria) doubtfully placed in southern Ahaggar (Lelièvre et al. 1993: fig. 7.2 [D5]). Numerous arthrodire remains associated with acanthodian scales assigned to Haplacanthus and Acanthodii indet. have been described and reported from the Emsian of Béchar Basin (Béni Abbès region; Lelièvre 1988; km 30, Nedjari et al. 2007: 71) (Fig. 1 [2]). Lehman (1964) described placoderms and Machaeracanthus Newberry, 1857 spines from southern Ahaggar and the Béni Abbès area, whereas associated acanthodian scales, partly corresponding to the material published here, were only mentioned. In Ajjers (Illizi Basin, Fig. $1[7,8]$ ) Emsian levels have yielded "fishes" and arthrodires (Fabre 2005: 277).

Lehman (1951, 1952a, b) mentioned remains of arthrodires from the Upper Devonian near Béni Abbès, Adrar Ahnet (Fig. 1 [5]), Adrar Mouydir (Lower Famennian) (Fig. 1 [6]) and Fort Polignac (now Illizi, Fig. 1 [7]). Famennian arthrodires are recorded from the Saoura valley (Fig. $1[1,2]$ ) (Fabre 1976: 129). More recently, Ginter et al. (2002) published chondrichthyan, acanthodian and actinopterygian microremains from the Upper Devonian of Gour Bedda ( $250 \mathrm{~km}$ east of In Salah; Fig. 1 [3], 2632'7'N, 4²4'17'E).

In the Carboniferous of Béchar (Fig. 1 [1]), isolated scales, possibly actinopterygians, have been reported (Fabre 1976: 190, 192). In the PermoCarboniferous of Ajjers Basin (Fig. 1 [8]), a level in the upper Tournaisian containing fish bones (Issendjel Formation, $27^{\circ} \mathrm{N}, 8-9^{\circ} \mathrm{E}$ ) and three levels with many fish remains (paleoniscids and selachians) (Tiguentourine Formation) are dated as latest Carboniferous or basal Permian (Fabre 1976: 196, 204). Later, Attar et al. (1981) recognized this material as elasmobranchians, acanthodians and actinopterygians, and confirmed a Stephanian-Autunian age. The Carboniferous of the Reggane Basin (Fig. 1 [4]) also yields fish scales (Fabre 1976: 214).

Lessard (1961) published sections from southern Ahaggar, along the Algeria-Mali-Niger borders. He reported Ctenacanthus major Agassiz, 1837, identified by J. P. Lehman, from the Carboniferous of the In Debirène syncline in the western part of the area (west of In Guezzam; Figs 1 [11]; 2 [2]). He also mentioned arthrodires in the Tin Seririne syncline (at the In Ateï-Taberia section, east of In Guezzam; Fig. 1 [9]) and in Oued Felaou (in front of In Guezzam; Fig. 1 [10]) from a level denoted F3 (Devonian). Later on, the mentions of an antiarch placoderm (Bothriolepis Eichwald, 1840) and a selachian (Ctenacanthus major) have been credited to Lessard (1961) by Fabre (1976: 230) in the Iullemmeden Basin, Taberia Formation (Upper Devonian-Lower Carboniferous) in the same area, but this time east of In Guezzam. Fabre probably mistook the location for Ctenacanthus major (essentially Carboniferous in age; Maisey 1981: 9), because Lessard organized the logs in his correlation table (1961: fig. 4) from left to right; that is, in the opposite way of his map (NE-SW and E-W directions).

\section{MATERIAL AND METHODS}

The specimens were collected in the Tassili, southern Oua-n-Ahaggar. According to Lehman (1964), the sample contains plates of Dolichothoraci and spinal plates of Petalichthyida, along with scales referred to acanthodians. In the same locality, occur conularids, tentaculites and spiriferids.

Two chondrichthyan teeth (MNHN.F.ALD-15, 16), 126 chondrichthyan scales and nine acanthodian scales have been extracted from the same sample (MNHN.F.ALD-12) by DG. 


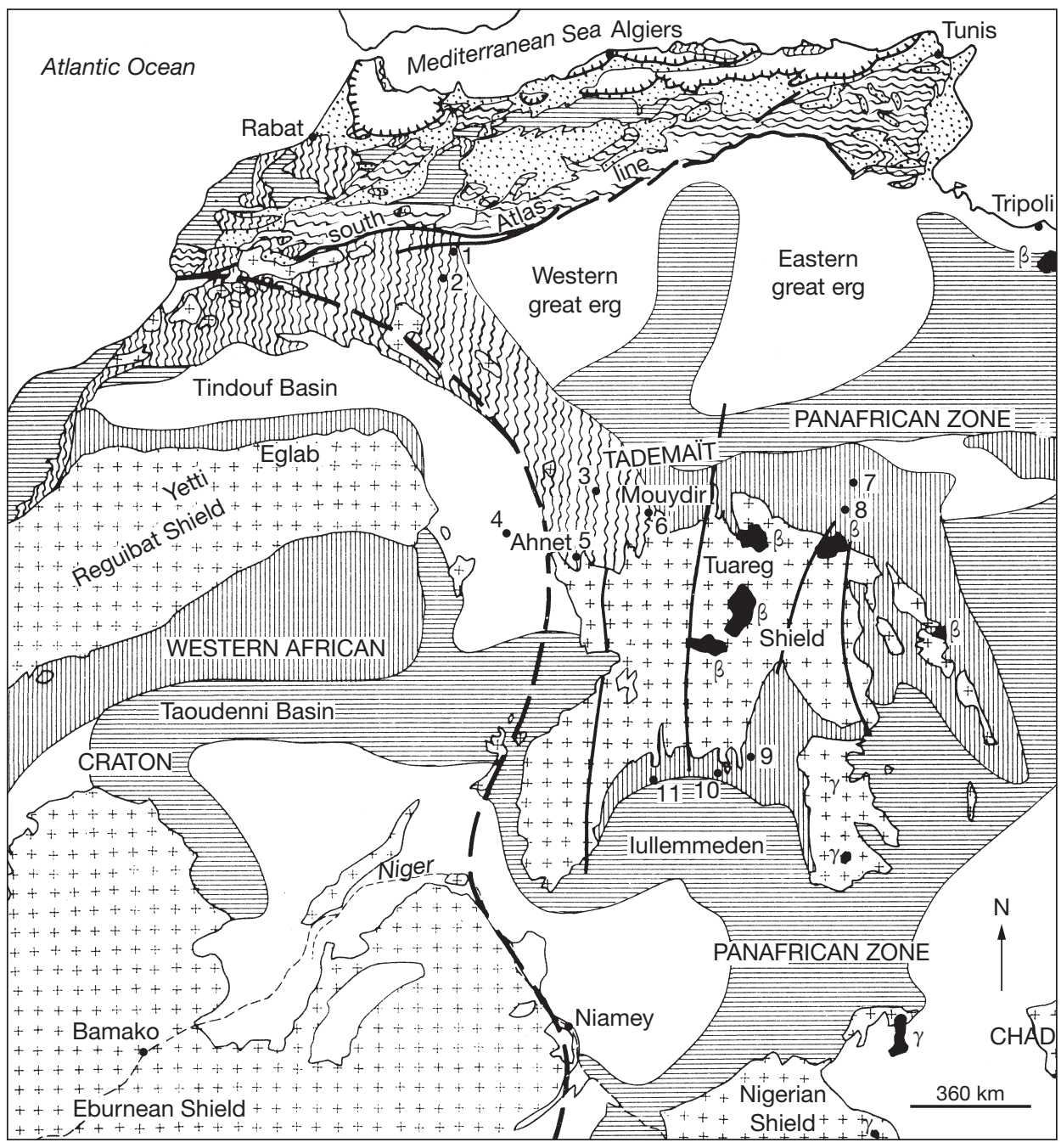

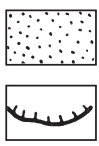

Tabular Tertiary and Quaternary molasses from alpine chain of Maghreb

Tertiary thrust sheet

(varied material)

Folded Secondary

Tabular Secondary

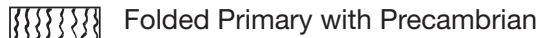
northern south-atlas line

Tabular Primary

Supposed Precambrian and Lower Cambrian from the Sahara

Recent magmatism of platform $\gamma$ : acid; $\beta$ basic.

FIG. 1. - Geological map of North-West Africa after Fabre (1976: 13). Numbers correspond to localities: 1, Bechar; 2, Béni Abbès; 3, In Salah (Gour Bedda); 4, Reganne; 5, Ahnet; 6, Mouydir; 7, Illizi (Fort Polignac); 8, Ajjers; 9, Tin Seririne Syncline (Anou In Ateï-Taberia); 10, Oued Felaou; 11, In Debirène. 


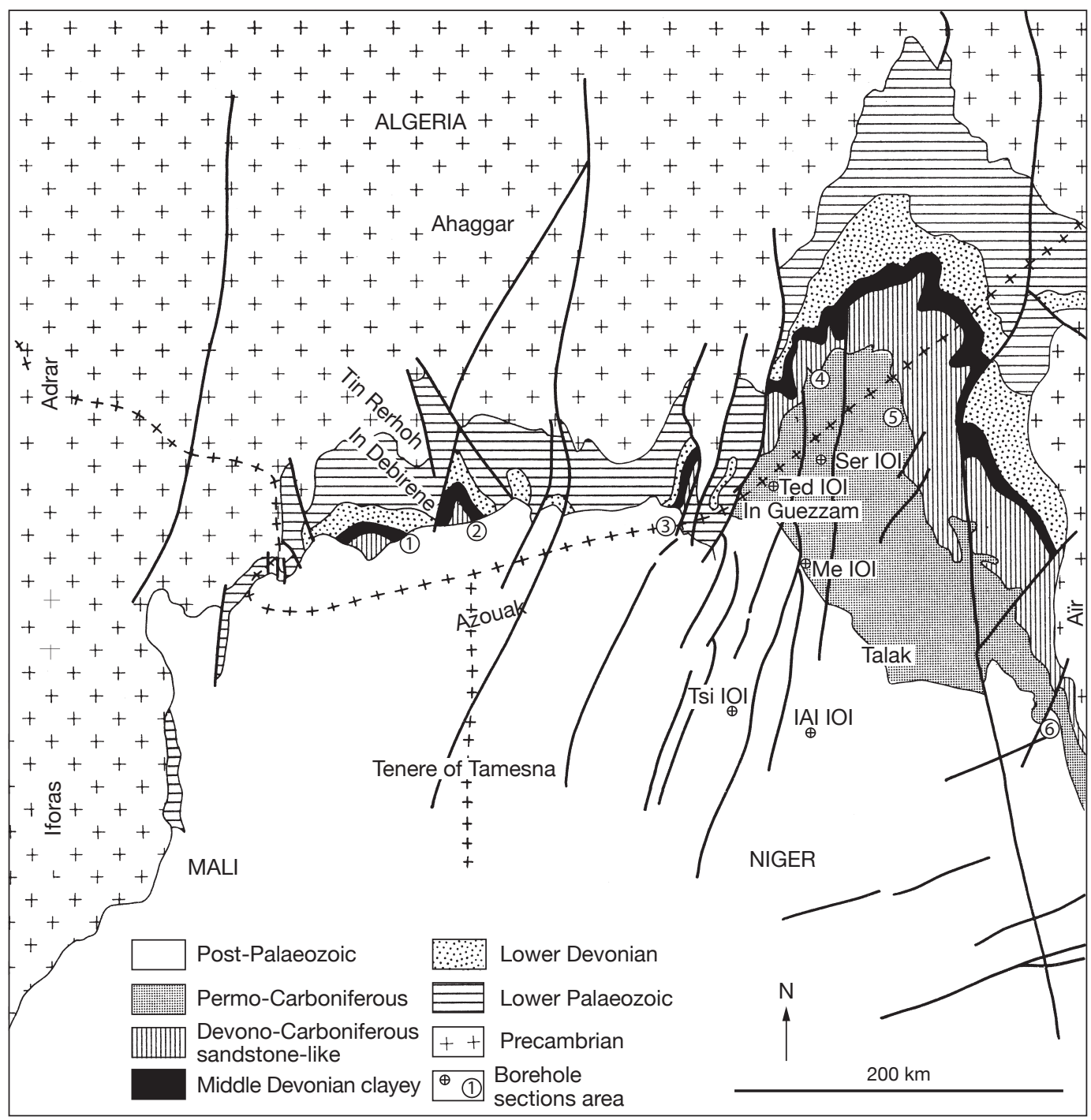

FIG. 2. - Geological map of the Devonian and Carboniferous in southern Ahaggar after Fabre (1976: 154). Localities: 1, In Debirène; 2, Tin Rerhoh; 3, Oued Felaou; 4, Anou Izileg; 5, Touaret-Tim Mersoï; 6, Talak.

\section{DETERMINATION OF AGE AND LOCALITY}

The only indication for the location of the material provided by Lessard was "sandstones from southern Oua-n-Ahaggar, Tassili" of supposed Pragian age (ex Siegenian) (Lehman 1964). The Petalichthyida published by Lehman is now considered as Emsian or Eifelian in age. Acanthodian scales derived from the sample, are here compared to Milesacanthus ancestralis Burrow, Lelièvre \& Janjou, 2006 from the Jawf formation (Saudi Arabia), dated as early Emsian (Burrow et al. 2006). The material was found with Arduspirifer ("Acrospirifer") arduennensis Mittmeyer, 1972 (Lehman 1964), also Emsian in age (Nicollin \& Ouali Mehadji pers. comm.).

A more accurate location of the outcrop may now be proposed. In southern Ahaggar, Palaeozoic outcrops 


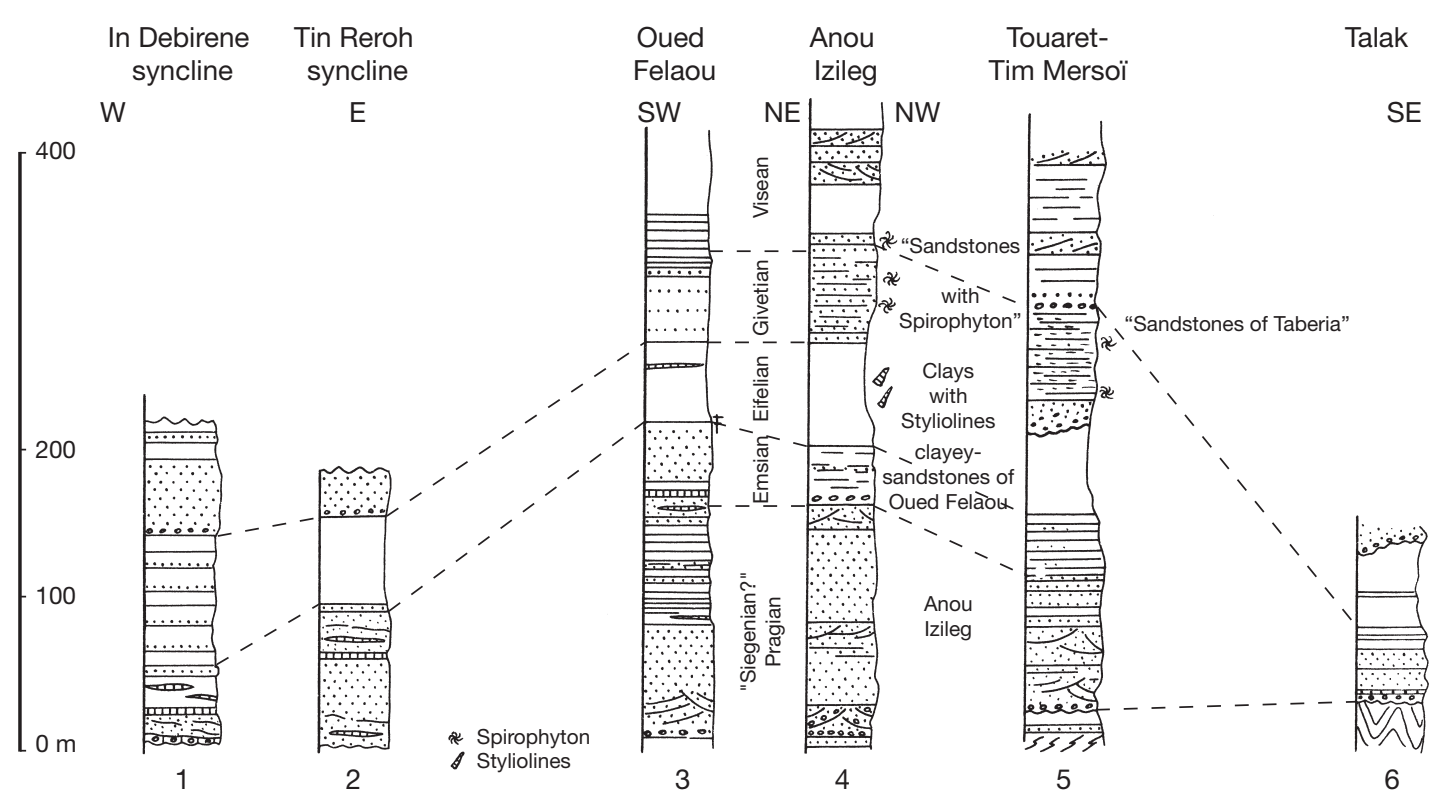

FIG. 3. - Stratigraphical sections of the Devonian and Carboniferous in southern Ahaggar after Fabre (1976: 155). Numbers of sections correspond to numbers of localities of Figure 2.

are fringing north of the Tamesna Basin or are located in the Tin Seririne syncline (western Aïr) (Fig. 2). The brachiopod Arduspirifer arduennensis, has also been found in Anou Izileg (Figs 2 [4]; 3 [4]), cut I (Tin Seririne syncline), where clay-sandstone levels named Oued Felaou (from the type locality) are dated as late Emsian (Claret \& Tempere 1965). A level denoted "F3" and dated as Pragian (ex Siegenian)-Emsian, and containing arthrodires, spiriferids, corals, and tentaculites, was mentioned by Lessard (1961) in two sections of the Tin Seririne syncline (cut I In Ateï-Taberia, east In Guezzam; Fig. 1 [9]) and Oued Felaou (cut J, north In Guezzam; Fig. 1 [10]). According to Fabre (1976: 153-155), two sections in South Ahaggar (Oued Felaou and Anou Izileg, eastern In Guezzam) show Emsian levels (Figs 2; $3)$. Tin Seririne $\left(17^{\circ} 25^{\prime} 0^{\prime \prime} \mathrm{N}, 6^{\circ} 16^{\prime} 60^{\prime \prime} \mathrm{E}\right)$ and Anou Izileg (wilaya Tamanghasset, $20^{\circ} 19^{\prime} 60^{\prime \prime} \mathrm{N}, 6^{\circ} 4^{\prime} 0^{\prime \prime} \mathrm{E}$ ) sections - the latter also mentioned by Claret $\&$ Tempere (1965) - are located about $120 \mathrm{~km}$ east of In Guezzam and are close to each other. This restricted the possibilities of location to less than $150 \mathrm{~km}$ from In Guezzam; i.e. the material must come from Oued Felaou (Figs 1 [10]; 2 [3]), In Ateï-Taberia, Tin Serir- ine syncline, or Anou Izileg (Fig. 1 [9]). The presence of Emsian levels containing "fishes" (arthrodires) is confirmed in sandstones (Oued Felaou Formation) east of In Guezzam (Fabre 2005: 279).

\section{SYSTEMATIC PALAEONTOLOGY}

Class CHONDRICHTHYES Huxley, 1880 Sub-class ELASMOBRANCHII Bonaparte, 1838 Cohort EUSELACHII Hay, 1902

Order incertae sedis

Family incertae sedis

\section{Genus Tassiliodus n. gen.}

TYPE SPECIES. — Tassilioduslessardin. sp. (MNHN.F.ALD-15, Fig. 4A).

Etymology. - From Tassili, origin of the material, and -odus, tooth.

DiAGNOSIS. - Crown with three diverging main cusps, the middle one being shorter than the two diverging lateral ones, intermediate cusplets in a more labial position than the main ones, rugose base oriented lingually. Scales 
with a flat base, a high neck and ridges on the crown, histological structure with an extensive network of wide vascular canals through the neck and base, box-in-box pattern, pallial dentine and mesodentine.

\section{Tassiliodus lessardi $\mathrm{n} . \mathrm{sp}$.}

(Fig. 4)

?Haplacanthus sp. - Lelièvre 1988: 300, fig. 5.

?Phoebodus sp. - Forey et al. 1992: 31, fig. 7.

Nogueralepis sp. - Burrow et al. 2006: 554, fig. 11: $12-$ 17, 23, 24.

"Chondrichthyan teeth, scales" - Derycke \& Goujet 2009: 87.

Tassiliodus lessardi "nomen nudum"- Derycke \& Goujet 2010: 145.

TyPe LOCAlity. - Near In Guezzam, Oued Felaou or Anou Izileg, southern Ahaggar (Algeria).

Etymology. - After L. Lessard, a hydrogeologist who discovered the material in the 1960 's.

Diagnosis. - As for genus.

SyNTYPES. - Teeth, MNHN.F.ALD-15 (Fig. 4A) and MNHN.F.ALD-16 (Fig. 4B); scales MNHN.F.ALD-17 to 35; thin sections MNHN.F.ALD-30-32, 34, 35.

OTHER MATERIAL EXAMINED. - 107 scales, same origin as the syntypes (see Material and methods).

\section{DESCRIPTION OF THE TEETH}

The tooth crown of MNHN.F.ALD-15 (Fig. 4A) bears 8 cusps and cusplets. Among the three main cusps, the middle one is half the height of the lateral cusps, that diverge at an angle of about $50^{\circ}$. The main cusps have a rounded tip. Five cusplets are visible, three on one side of the central cusp and two on the other side. Lateral cusplets are not in the same plane, and the smallest ones are in a more labial position. The smooth crown is probably covered with enameloid, and only one ridge is visible in the middle of a main cusp (right side in Fig. $4 \mathrm{~A}_{1}$ ).

The base is perpendicular to the crown and expanded lingually. Its internal structure is revealed by a fracture surface showing bone or osteodentine
(Fig. $4 \mathrm{~A}_{3}$ ) with a rugose external aspect (Fig. $4 \mathrm{~A}_{4}$ ). There is apparently no regular organization of the foramina in the base (Fig. $4 \mathrm{~A}_{4}, \mathrm{~A}_{5}$ ).

The crown of the second, smaller tooth MNHN.F.ALD-16 (Fig. 4B) is only visible in lingual aspect and made up by four cusps with 3 diverging main cusps (angle around $50^{\circ}$ ). The tip of the cusps are more pointed and slender than in MNHN.F.ALD-15. The rugose base shows a kind of lingual bulge behind the central cusp (Fig. 4B $)$. One cusplet is visible but is not in the same plane, it is situated more labially, like in MNHN.F.ALD-15. The base is poorly developed and the cusps are oriented or curved lingually. Tiny foramina are visible in the lingual part of the base.

\section{Remarks}

Our specimens have been compared with other Emsian chondrichthyans: Doliodus Traquair, 1893, known from an articulated specimen (Turner \& Miller 2005: fig. 6) as well as isolated teeth, Protodus Woodward, 1892 (Turner \& Miller 2008), Pucapampella Janvier \& Suarez-Riglos, 1986 (Maisey \& Anderson 2001), and possible Emsian Antarctilamna Young, 1982 (e.g., Forey et al. 1992).

Devonian levels of Saudi Arabia have yielded early vertebrate material. A tooth referred to Phoebodus sp. (Forey et al. 1992: fig. 7) has been described from the Jauf Formation (Saudi Arabia) and dated as Pragian to Early Emsian. Although it is only illustrated by a drawing and in lingual aspect, it is possibly an antarctilamnid, a family mainly known from the Givetian-Frasnian (type genus Antarctilamna). However this tooth appears smooth and shows fewer vascular foramina than Antarctilamna and is not comparable to Tassiliodus $\mathrm{n}$. gen. which shows no big foramina. Antarctilamna is also represented by spines and scales in the Wajid Formation (Saudi Arabia, Pragian to Early Emsian) (Forey et al. 1992). Other "shark" material corresponds to "Cladodus" teeth, that are not identifiable according to Ginter (2004). One species, A. seriponensis, was also described from the Emsian of Bolivia (Gagnier et al. 1988) based on fin spines. Antarctilamna teeth are characterized by many ridges on the cusps (Young 1982; Long \& Young 1995), a feature that is absent in our specimens. 


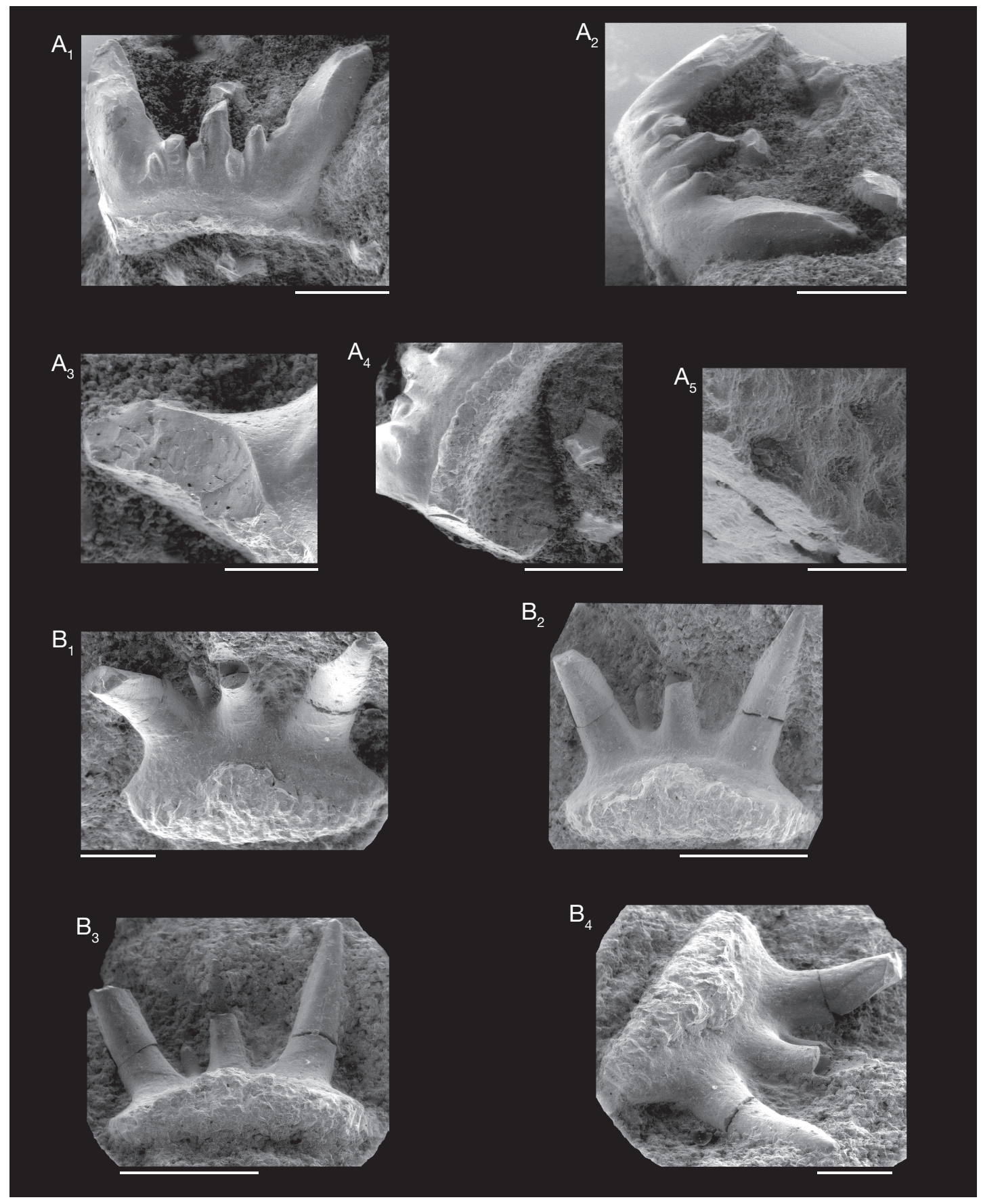

FIG. 4. - Chondrichthyan teeth of Tassiliodus lessardi n. gen., n. sp. from the Emsian (Devonian) of southern Algeria: A, MNHN.F.ALD-15; $\mathbf{A}_{1}$, labial view; $\mathbf{A}_{2}$, labio-lateral view; $\mathbf{A}_{3}$, enlargement of the base; $\mathbf{A}_{4}$, basal view; $\mathbf{A}_{5}$, enlargement of the basal view; $\mathbf{B}$, MNHN.F.ALD-16, lingual views. Scale bars: $A_{1}, A_{2}, A_{4}, B_{2}, B_{3}, 2 \mathrm{~mm} ; A_{3}, B_{1}, B_{4}, 1 \mathrm{~mm} ; A_{5}, 200 \mu \mathrm{m}$. 
Pucapampella first found in Bolivia (Janvier \& Suarez-Riglos 1986) is also known from the upper Emsian in South Africa (Anderson et al. 1999; Maisey \& Anderson 2001 in Maisey 2004). It is only known by its braincase and no teeth have been yet described (Maisey 2001).

Doliodus problematicus Woodward, 1892, is early Emsian in age (Canada) and shows trunk scales (Miller et al. 2003: 503) that resemble those of Antarctilamna from the Jauf Formation. Doliodus teeth have cusps similar to some xenacanthiform ones and have been included in the Omalodontida (Miller et al. 2003). Known as one of the oldest articulated chondrichthyans, Doliodus possesses paired fin-spines, a character long considered as a synapomorphy of acanthodians, but now as a gnathostome symplesiomorphy (Miller et al. 2003). Turner (2004) described the teeth of Doliodus in detail. The main difference with Tassiliodus n. gen. concerns their base, which is oriented labially in Doliodus, hence its inclusion in the Omalodontida. The crowns are also different: in Doliodus one of the main lateral cusps is larger than the other, the proportions in length of cusps are different, and intermediate cusplets are in the same plane as the main cusps.

Protodus jexi Woodward, 1892 from New Brunswick (Canada) (late Pragian/early Emsian) is quite different, as it has monocuspid teeth (Turner \& Miller 2008).

Finally among Emsian chondrichthyans, the Tassiliodus n. gen. teeth show a unique morphology.

Leonodus Mader, 1986, first described by Mader (1986) from Lochkovian-Pragian levels of Spain, is considered as the oldest unequivocal chondrichthyan teeth (Turner 2004; Turner \& Miller 2005). It is bicuspid, more acute when sharpened by wear (Botella et al. 2009), and is the first indication of a dental lamina (Botella 2006, except for placoderms according to Smith \& Johanson 2003, even there is a regular tooth addition without a true dental lamina, M. M. Smith pers. comm.).

\section{DESCRIPTION OF THE SCALES}

From the $c .126$ scales, six morphotypes have been identified as belonging to the squamation of Tassiliodus lessardi n. gen., n. sp.
High-neck scales, almost 58 scales (Fig. 5A-D)

These four scales share a crown that shows wide grooves intercalated with converging thin, sometimes nodose, ridges in the middle, an elongate neck and a flat base, that is narrower than the crown. These scales are generally higher than wide.

The crown of MNHN.F.ALD-17 (Fig. 5A) bears six main tuberculated ridges converging at the top. One ridge is divided near the crown margin (right on Fig. $5 \mathrm{~A}_{1}$ ). One intermediate ridge seems to merge on the opposite side. This round scale has a high neck and a flat base with one basal pore and a notch near its margin (Fig. $5 \mathrm{~A}_{2}$ ). In the scale MNHN.F.ALD-18 (Fig. 5B), more numerous ridges begin in the vertical part of the crown, converging at the top, nipped-in waist and high neck with one foramen at the extreme basal part of the neck.

In the scale MNHN.F.ALD-19 (Fig. 5C), one foramen in the middle of the base and one tiny lateral foramen, could correspond in position to the "pulp" cavity "openings" described in Elegestolepis grossi Karatajute-Talimaa, 1973 (Karatajute-Talimaa 1973: taf. 3), but in our scale there is no pulp cavity, so they are strictly vascular foramina.

A bigger scale, MNHN.F.ALD-20 (Fig. 5D), shows about nine ridges converging and reaching the top and slightly displaced. Smaller ridges starting at the margin of the crown are intercalated between them. The crown outline is oval and the margin crenulated. The elliptical base has the same orientation as the crown. In basal view (Fig. $5 \mathrm{D}_{2}$ ), a tenuous limit underlines the boundary between the crown and the neck.

\section{Flat-crowned scales (Fig. 5E-G)}

The scales MNHN.F.ALD-21 to 23 are flatter. The upper crown is ornamented with 4-7 ridges converging backward and separated by wide grooves. The lower lateral crown is either smooth (Fig. 5E $\mathrm{E}_{1}$ ), or with ridges parallel or perpendicular (Fig. $5 \mathrm{~F}_{1}$ ) to the central crown ridges. The flat base, narrower than the crown, may show two foramina in MNHN.F.ALD-22 (Fig. 5F 2 ): one near the centre and one near the margin.

The morphology of the scales is similar to that of Wetteldorfia triangula Vieth-Schreiner, 1983 (Vieth-Schreiner 1983: taf. 1. 1-9; Emsian-lower 


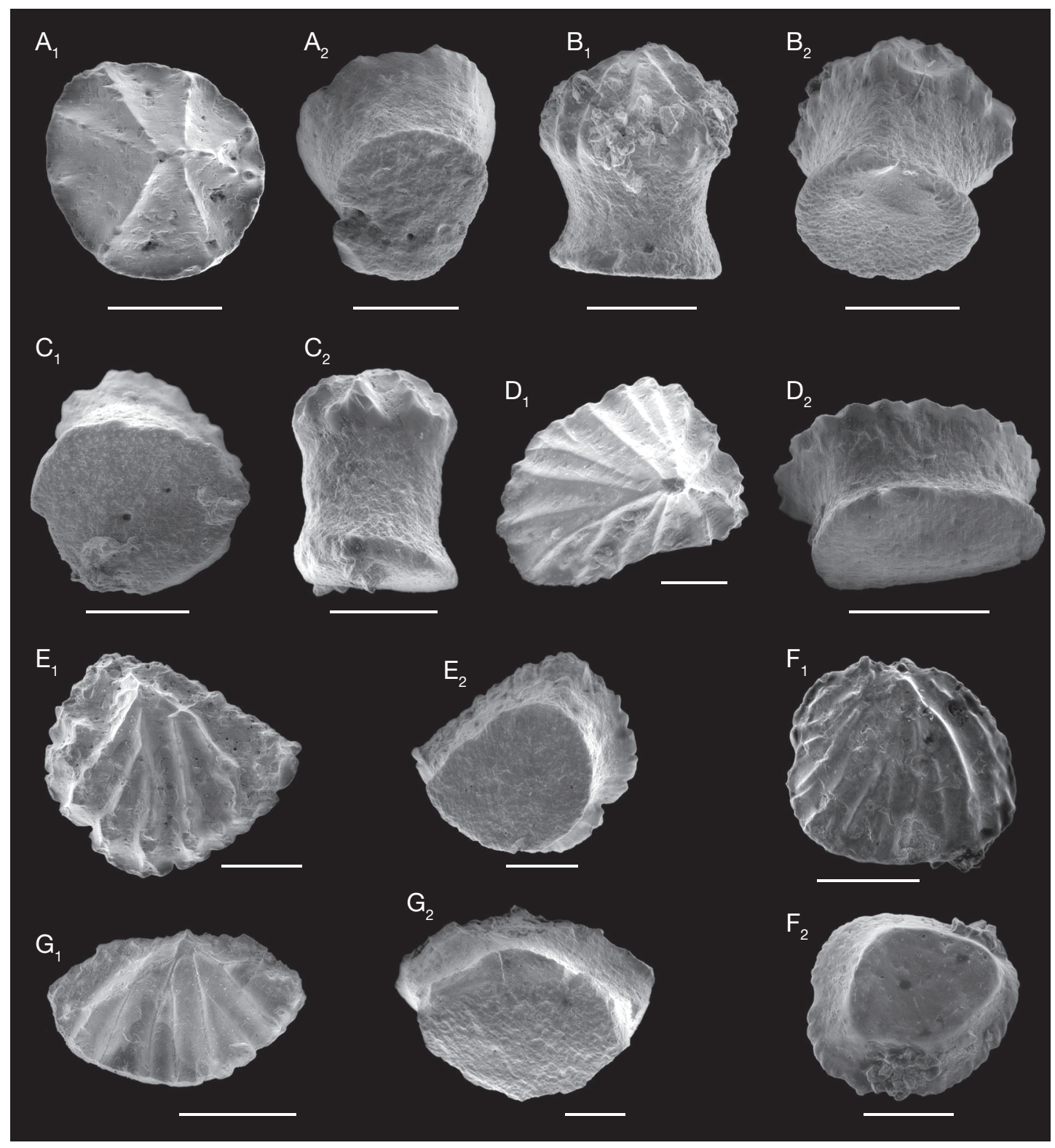

FIG. 5. - Chondrichthyan scales of Tassiliodus lessardi n. gen., n. sp. from the Emsian (Devonian) of southern Algeria: A, MNHN.F.ALD-17; $\mathbf{A}_{1}$, crown view; $\mathbf{A}_{2}$, basal view; B, MNHN.F.ALD-18; $\mathbf{B}_{1}$, lateral view; $\mathbf{B}_{2}$, basal view; C, MNHN.F.ALD-19; $\mathbf{C}_{1}$, basal view; $\mathbf{C}_{2}$, lateral view; D, MNHN.F.ALD-20; $\mathbf{D}_{1}$, crown view; $\mathbf{D}_{2}$, basal view; E, MNHN.F.ALD-21; $\mathbf{E}_{1}$, crown view; $\mathbf{E}_{2}$, basal view; F, MNHN.F.ALD-22; $\mathbf{F}_{1}$, crown view; $\mathbf{F}_{2}$, basal view; G, MNHN.F.ALD-23; $\mathbf{G}_{1}$, crown view; $\mathbf{G}_{2}$, basal view. Scale bars: A, B, $\mathbf{C}_{2}, D_{1}, E, F, G 2,500 \mu m$; $\mathrm{C}_{1}, 400 \mu \mathrm{m} ; \mathrm{D}_{2}, \mathrm{G}_{1}, 1 \mathrm{~mm}$.

Eifelian), which is considered as an acanthodian. Here the circular base is smaller than the crown whereas Wetteldorfia Vieth-Schreiner, 1983 shows a forwardly displaced, diamond-shaped base. The scales are smaller $(1-1.5 \mathrm{~mm})$ than those of Wetteldorfia $(3 \mathrm{~mm})$. The histological structure of 
some scales of Wetteldorfia from the Eifel (ViethSchreiner 1983: abb. 7, 8) recalls that of the highneck scales (Figs 5A-D; 7 $\mathrm{E}_{2}$ ), with a box-in-box structure with only two or three growth lines in the crown, which do not continue in the base. In Vieth-Schreiner's drawings, internal growth zones seem to terminate before the surface. Furthermore, the same tissues are visible in the same position. Usually, in the center of the crown of acanthodian scales, a primordium is visible. It is present neither in the thin sections of Wetteldorfia from the Eifel, nor in our material (morphologically more closely corresponding to Figure 5A-D; the material that shows the external morphology of Wetteldorfia has not been sectioned). Wetteldorfia is also described from the Emsian of Saudi Arabia (Burrow et al. 2006: figs 4.12, 13, 15, 16) but is different from the type species, and Burrow et al. (2006: 544) proposed a revised diagnosis of the genus.

\section{Leaf-shaped scales (Fig. 6A, B)}

These flat diamond-shaped scales show ridges converging in the centre of the convex crown, some very worn (ALD-25; Figs $6 \mathrm{~B}_{1} ; 7 \mathrm{~B}_{2}$ ) and others less so (ALD-24; Fig. 6A1). Shorter ridges appear on the lateral sides of the crown (Fig. $6 \mathrm{~A}_{2}$, $\mathrm{B}_{2}$ ). The flame outline corresponds to two concave opposite sides and two other more convex

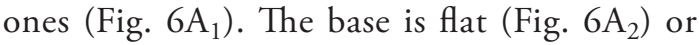
slightly convex (Fig. $6 \mathrm{~B}_{2}$ ). The neck is short and nipped-in waist (Fig. 6A 2 ). These scales are wider than high.

\section{Spiny scale (Fig. 6F)}

A spiny crowned scale, MNHN.F.ALD-29, has a nipped-in waist, high neck and a flat base (Fig. $6 \mathrm{~F}_{2}$ ). Three broad spines are distributed with one at the top of the crown and two on one side (Fig. $6 \mathrm{~F}_{1}$ ). Smaller, more irregularly distributed, spines may be joined by a crest to the highest spine in two files (Fig. 6F $\mathrm{F}_{1}$ ). It resembles isolated tubercles of the scale MNHN.F.ALD-17 (Fig. 5A $A_{1}$ ).

Scales with parallel ridges on the crown (Fig. 6C, D) The two scales MNHN.F.ALD-26, 27 have a flat, posteriorly elongated crown. The crown is orna- mented with four, strong, subparallel ridges - the biggest one in the middle - separated by wide grooves (Fig. $6 \mathrm{C}_{1}$ ). The second scale MNHN.F.ALD-27 shows seven ridges beginning in the anterior part, and two supplementary ones intercalated in the posterior part $\left(\right.$ Fig. $\left.6 \mathrm{D}_{2}\right)$. The bases are different in these two scales: more flat for MNHN.F.ALD-26 (Fig. $6 \mathrm{C}_{2}$ ) and more convex and diamond-shaped for MNHN.F.ALD-27 (Fig. 6D 1 ) with a foramen in a lateral position.

The scale MNHN.F.ALD-26 (Fig. 6C 1 ) evokes a scale of Elegestolepis grossi Karatajute-Talimaa, 1973, from the Silurian of Tuva (Karatajute-Talimaa 1973: taf. 3, figs 5c, 6a), with a high neck and a flat base, and is associated with scales showing a more diamond-shaped base, like that in MNHN.F.ALD-27 (Fig. 6D1).

\section{Broken scale (Fig. 6E)}

The broken scale MNHN.F.ALD-28 shows a rounded convex base protruding forward of the crown (Fig. 6E $\mathrm{E}_{1}$ ). One foramen is visible on the high neck. The fore-crown displays ridges that are inserted low on the base.

\section{SCALES HISTOLOGY}

Thin section $1 \mathrm{MNHN}$.F.ALD-30 (Fig. $7 \mathrm{~A}_{2}$ ), thin section $3 \mathrm{MNHN}$.F.ALD-32 (Fig. $7 \mathrm{C}_{2}$ ) and thin section $5 \mathrm{MNHN}$.F.ALD-35 (Fig. $7 \mathrm{H}_{2}$ ) are vertical sections of scales with a high neck, converging crown ridges and a flat base (Fig. 5A-D). Thin sections 2 MNHN.F.ALD-31 (Fig. 7B 1 ) and 4 MNHN.F.ALD-34 (Fig. 7E 2 ) are of flatter scales like MNHN.F.ALD-24 and 25 (Fig. 6A, B). Thin section $4 \mathrm{MNHN}$.F.ALD-34 (Fig. $7 \mathrm{E}_{2}$ ) is of a scale that is wider than high, but also with wide grooves and thin ridges converging at an eccentric apex. In the Figure 7, each thin section corresponds to the nearest scale morphology and bears the same letter.

Almost the entire scale internal structure comprises a network of meandering canals emerging in any part of the scale; canals can open out on the base (Figs $7 \mathrm{~A}_{2}, \mathrm{C}_{2} ; 5 \mathrm{~A}_{2}, \mathrm{C}_{1}$ ), the neck (Figs $7 \mathrm{C}_{2} ; 5 \mathrm{~B}_{1}$ ) or on the crown (Fig. $7 \mathrm{C}_{2}, \mathrm{H}_{1}$, $\mathrm{H}_{2}$ ). It consists of a distinctive type of mesodentine (Ørvig 1967). 


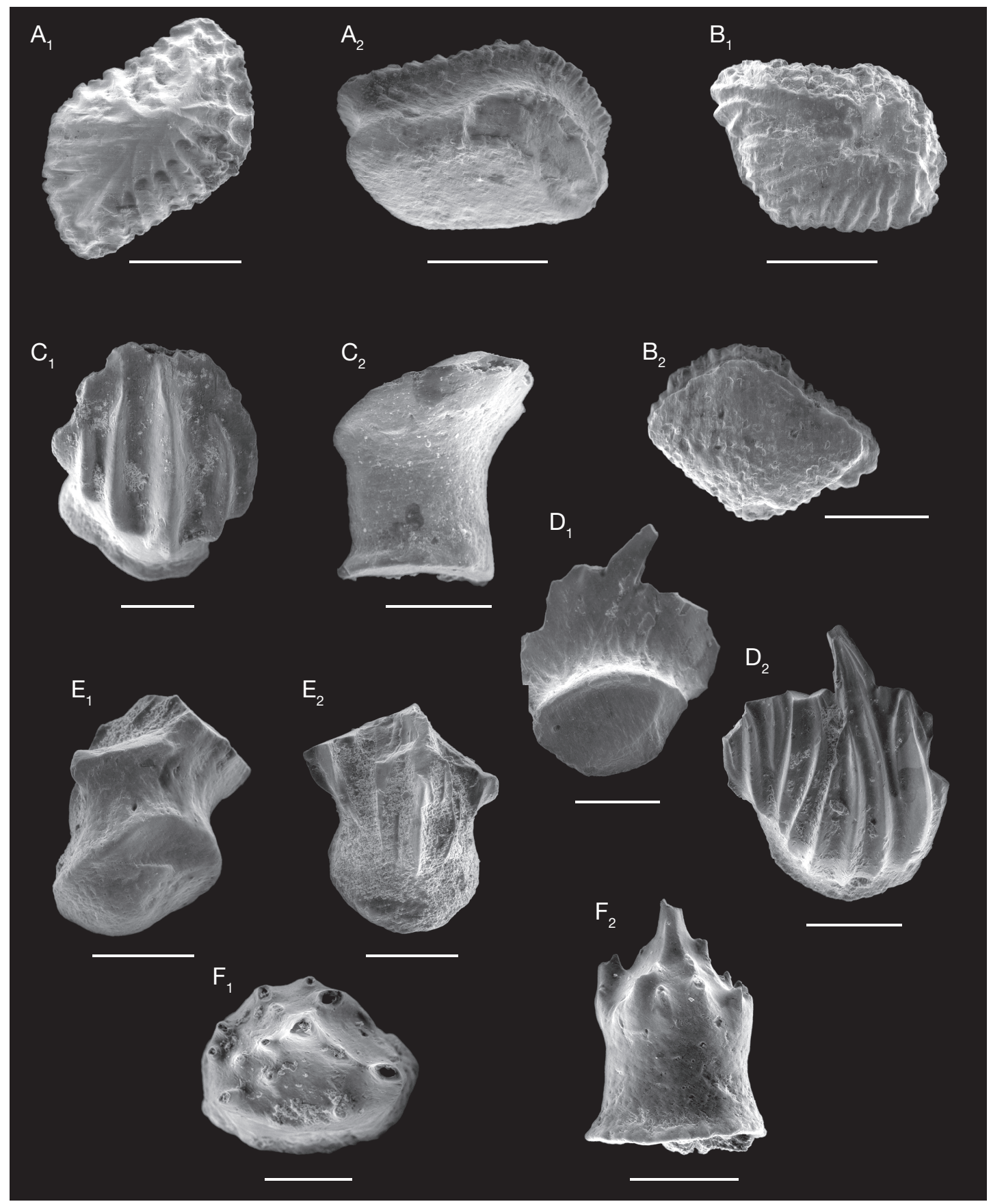

FIG. 6. - Chondrichthyan scales of Tassiliodus lessardi n. gen., n. sp. from the Emsian (Devonian) of southern Algeria: A, MNHN.F.ALD-24; $\mathbf{A}_{1}$, crown view; $\mathbf{A}_{2}$, basal view; B, MNHN.F.ALD-25; $\mathbf{B}_{1}$, crown view; $\mathbf{B}_{2}$, basal view; C, MNHN.F.ALD-26; $\mathbf{C}_{1}$, crown view; $\mathbf{C}_{2}$, lateral view; $\mathbf{D}$, MNHN.F.ALD-27; $\mathbf{D}_{1}$, basal view; $\mathbf{D}_{2}$, crown view; E, MNHN.F.ALD-28; $\mathbf{E}_{1}$, latero-basal view; $\mathbf{E}_{2}$, front view; F, MNHN.F.ALD-29; $\mathbf{F}_{1}$, crown view; $\mathbf{F}_{2}$, lateral view. Scale bars: $A, B, 1 \mathrm{~mm} ; \mathrm{C}_{1}, \mathrm{~F}_{1}, 200 \mu \mathrm{m} ; \mathrm{C}_{2}, \mathrm{~F}_{2}, 300 \mu \mathrm{m} ; \mathrm{D}, 500 \mu \mathrm{m} ; \mathrm{E}, 400 \mu \mathrm{m}$. 
A kind of box-in-box pattern is visible in the crown, but some elements of the previous generations of the scale may appear at the surface. Whereas thin section 3 MNHN.F.ALD-32 (Fig. $7 \mathrm{C}_{2}$ ) only shows one growth zone, thin sections 1, 2 and 5 show two growth stages (Fig. $7 \mathrm{~A}_{2}$, $\mathrm{B}_{1}, \mathrm{H}_{2}$ ), with possibly more for thin section 4 MNHN.F.ALD-34 (Fig. 7E 2 ), based on the undulating ridges. The first stage, mainly invaded by the vascular canal network, emerges on the right side on MNHN.F.ALD-35 (Fig. $7 \mathrm{H}_{2}$ ) and on the left one in MNHN.F.ALD-34 (Fig. 7 $\mathrm{E}_{2}$ ). It may correspond to the intermediate external shorter ridges at the crown base (Fig. $\left.7 \mathrm{E}_{1}\right)$. It means that the overlapping by the second growth stage is not complete and that this histology does not exactly correspond to a real box-in-box pattern.

Resorption-remobilization phenomena are observed: on the left side of the tip of MNHN.F.ALD-30 (Fig. $7 \mathrm{~A}_{2}$ ), in the middle part and right side of MNHN.F.ALD-34 (Fig. 7 $\mathrm{E}_{2}$ ) and in the middle bulge of the first stage MNHN.F.ALD-35 (Fig. $7 \mathrm{H}_{2}$ ). Resorption was never found before in chondrichthyans, except in Ctenacanthus sp. from the Namurian (Derycke-Khatir 2005).

More classically, bushes of pallial dentine ( $\mathrm{Ra}$ dinsky 1961) radiate from vascular canals under the crown surface, sometimes lined by a thin refringent layer. Two levels of dentine may appear inside the crown, for example in thin sections 1 MNHN.F.ALD-30, 4 MNHN.F.ALD-34 and 5 MNHN.F.ALD-35 (Fig. 7A $, \mathrm{E}_{2}, \mathrm{H}_{2}$ ). Sharpey's fibers and osteocytes are localized in the extreme basal part of the scales, and may be particularly dense in thin sections 1 MNHN.F.ALD-30 and 5 MNHN.F.ALD-35 (Fig. 7A2, H2). In thin section 4 MNHN.F.ALD-34 (Fig. 7E2) the osteocytes are not randomly organized, surrounding vascular canals. The density and the organization of Sharpey's fibers and osteocytes are variable, possibly reflecting the maturity of the scale.

In two thin sections (1 MNHN.F.ALD-30 and 2 MNHN.F.ALD-31, Fig. $7 A_{2}, B_{1}$ ), a short canal joining an aperture in the posterior part and in the basal part of the base corresponds to the openings and the notch visible on MNHN.F.ALD-17 (Fig. $5 \mathrm{~A}_{2}$ ).
Scale histology appears almost identical in the material of Algeria and in the "Nogueralepis sp." scales from the Jauf Formation of Saudi Arabia (Burrow et al. 2006: fig. 11: 12-17, 23, 24). Crown ridges converge backwards or are subparallel in "Nogueralepis sp.", and the scales have the same morphology as those of Tassiliodus lessardi n. gen., n. sp., with a very high neck and a flat base. They strickingly differ from those of the type-species of Nogueralepis Wang, 1993 from the Lochkovian of Spain (Wang 1993), particularly in their histology. The scales from Saudi Arabia were probably misidentified and may in fact belong to our new taxon Tassiliodus n. gen., reinforcing the close biogeographic affinity between these two areas.

Thin section $4 \mathrm{MNHN}$.F.ALD-34 (Fig. 7E 2 ) evokes a thin section of a tiny adult scale of Elegestolepis grossi from the Silurian of Tuva (KaratajuteTalimaa 1973: 42, abb. 3, E), but also the thin section of Wetteldorfia from Saudi Arabia, except for the growth zones of the base (Burrow et al. 2006: fig. 4: 16).

\section{CONCLUSION FOR CHONDRICHTHYAN SCALES}

Scales with the morphology shown by MNHN.F. ALD-17, 19 (Fig. 5A-D) and histology with the network of meandering canals as in MNHN.F.ALD-30, 32 (Fig. $7 \mathrm{~A}_{2}, \mathrm{C}_{2}$ ) resemble those of "Nogueralepis sp." from Saudi Arabia (Burrow et al. 2006: fig. 11: 12-17, 23, 24). The scales MNHN.F.ALD-21-23 (Fig. 5E-G) morphologically resemble Wetteldorfia scales (Vieth-Schreiner 1983: taf. 1.1-9), but the different morphotype of scales MNHN.F.ALD-17-19 (Fig. 5A-D) corresponds to the histology of Wetteldorfia (Fig. $7 \mathrm{E}_{1}$, $\mathrm{E}_{2}$ ). Thin section MNHN.F.ALD-34 (Fig. 7E 2 ) also evokes the histology of Elegestolepis, except for the lack of a pulp cavity and its finer calibre canals (Karatajute-Talimaa 1973: 42, abb. 3, E). Two other scales, MNHN.F.ALD-26, 27 (Fig. 6C, D), resemble the morphology of Elegestolepis (Karatajute-Talimaa 1973: taf. 3, figs 5c, 6a).

The distinctive histological structure indicates that all these scales may belong to the squamation of the same chondrichthyan. 

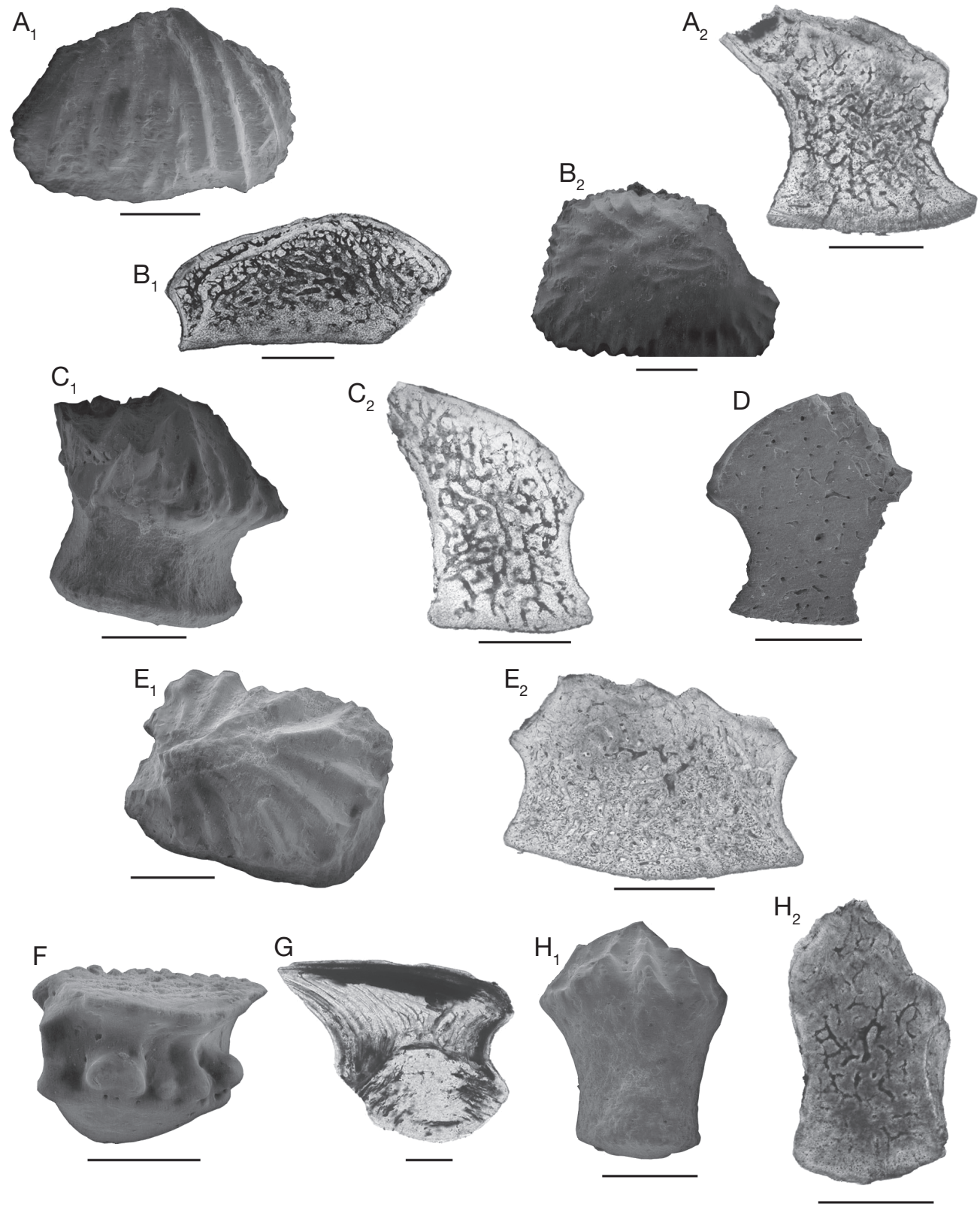

FIG. 7. - Histology and corresponding morphology of chondrichthyan scales from the Emsian (Devonian) of southern Algeria: A-E, H, Tassiliodus lessardi n. gen., n. sp.; F, G, Milesacanthus cf. ancestralis; identical letters refer to the same scale in morphology and in thin section (except for $\mathbf{D}$, corresponding to an internal view of a broken scale photographed by SEM, and for $\mathbf{F}$, which was lost in the SEM); A, crown view and sagittal thin section 1 of a scale with converging ridges posteriorly and high-neck (MNHN.F.ALD-30); B, thin section 2 and crown view of a dumpy scale with radiating ridges only fringing the crown (MNHN.F.ALD-31); C, lateral view of a high-neck scale and thin section 3 (MNHN.F.ALD-32); D, SEM micrograph of internal view of a high-necked scale (MNHN.F.ALD-33); $\mathbf{E}$, crown view of a dumpy scale with radiating ridges reaching the middle of the scale, and thin section 4 (MNHN.F.ALD-34); H, lateral view of a scale with converging ridges in the middle of the scale and a high neck, and thin section 5 (MNHN.F.ALD-35); F, posterolateral view (MNHN.F.ALD-40); G, thin section 9 (MNHN.F.ALD-41). Scale bars: A-E, H, $500 \mu \mathrm{m} ; \mathrm{F}, 300 \mu \mathrm{m} ; \mathrm{G}, 100 \mu \mathrm{m}$. 
Class ACANTHODII Owen, 1846

Order Indeterminate

Family DiplacantHIDAE Woodward, 1891

Genus Milesacanthus Young \& Burrow, 2004

TYPe SPECIES. - Milesacanthus antarctica Young \& Burrow, 2004: 26-38, figs 1-5, 6h, o-r.

\section{Milesacanthus cf. ancestralis}

(Fig. 8)

Material. - Nine scales, one of which is lost (MNHN.F.ALD-40), and one thin section MNHN.F.ALD-41.

\section{DESCRIPTION}

The crown of these four scales is diamond-shaped and its anterior part may be more rounded as in MNHN.F.ALD-38 (Fig. 8C 2 ). The convex base, also diamond-shaped, and with anterior and rounded posterior edges is located anteriorly.

The scales with a flat crown show sub-parallel grooves (18 for Fig. 8 $\mathrm{A}_{1}, \mathrm{~B}_{2}$ and possibly more), diverging in the front part (Fig. $8 \mathrm{C}_{2}$ ), like in the material of Milesacanthus ancestralis from Saudi Arabia. The grooves are not really deep but narrower than the ridges. Both grooves and ridges run along the entire crown length of the scale. In the scale MNHN.F.ALD-36 (Fig. 8 $\mathrm{A}_{1}$ ), grooves and ridges start just at the front edge of the scale, whereas in the scale MNHN.F.ALD-37 (Fig. $8 \mathrm{~B}_{2}$ ) the ridges start at the vertical edge of the crown and the posterior edge is more crenulated.

One scale (ALD-38) shows 13 larger grooves (Fig. $8 \mathrm{C}_{2}$ ), but only in its anterior part. Pore openings, located mainly at the beginning of the grooves, connect to an ascending canal system. The grooves begin after the anterior edge of the crown and most lateral grooves undulate, slightly converging in the beginning, then parallel to the diagonal, and stop in the posterior third of the crown. The neck is well marked with a row of foramina posteriorly and anteriorly (Fig. $8 \mathrm{~A}_{2}, \mathrm{~B}_{2}, \mathrm{C}_{2}$ ). Furthermore, wart-like protuberances are visible on the posterior neck (Fig. $8 \mathrm{~A}_{2}$; more evident on Fig. 7F), visible on "young" scales according Burrow et al. (2006: 547).

\section{Histology}

The thin section 9 MNHN.F.ALD-41 (Fig. 7G) shows a classical pattern for an acanthodian, with a primordium in the middle of the crown that is made of dentine covered with thin box-in-box growth zones continuing from the crown into the acellular bone base. Contrary to Milesacanthus ancestralis and $M$. antarctica (Young \& Burrow 2004), no vascular canal was found, but only one thin section has been made.

\section{DISCUSSION}

The number and the development of ridges on the crown recalls the scales of $M$. antarctica, but the presence of wart-like bumps in the posterior part of the neck is more suggestive of $M$. ancestralis. Although wide canals were not detected here, they are present in both $M$. ancestralis and $M$. antarctica, and pore openings are visible at the surface of the scale MNHN.F.ALD-38 (Fig. 8C 2 ). The cone of the base inserted in the crown is, in our material, more developed. In conclusion, some acanthodian scales are closer to $M$. antarctica and the others to $M$. ancestralis but their histology is different.

\section{DISCUSSION}

\section{Palaeobiology}

The earliest chondrichthyans are considered to have been toothless, with a gap of about 50 millions of years between the first putative scales and the first teeth (Turner 2004). The first undoubted chondrichthyan teeth belong to Leonodus (diplodont or bicuspid) from the Lochkovian/Pragian of Spain. Multicuspidate "cladodont" teeth are considered to appear later (Maisey \& Melo 2005: 500). Until now, three other undisputed Emsian chondrichthyan genera were known: Pucapampella without described teeth, Doliodus with articulated remains and Protodus (monocuspid) only known from teeth (Turner \& Miller 2005, 2008). Protodus is the first to show predator style teeth according to Turner \& Miller (2008: 140). Doliodus with its diplodont teeth (Maisey \& Melo 2005) is included in the Omalodontidae (Turner 2004; Turner \& Miller 2008). Some Emsian bicuspid teeth with intermediate cusplets 


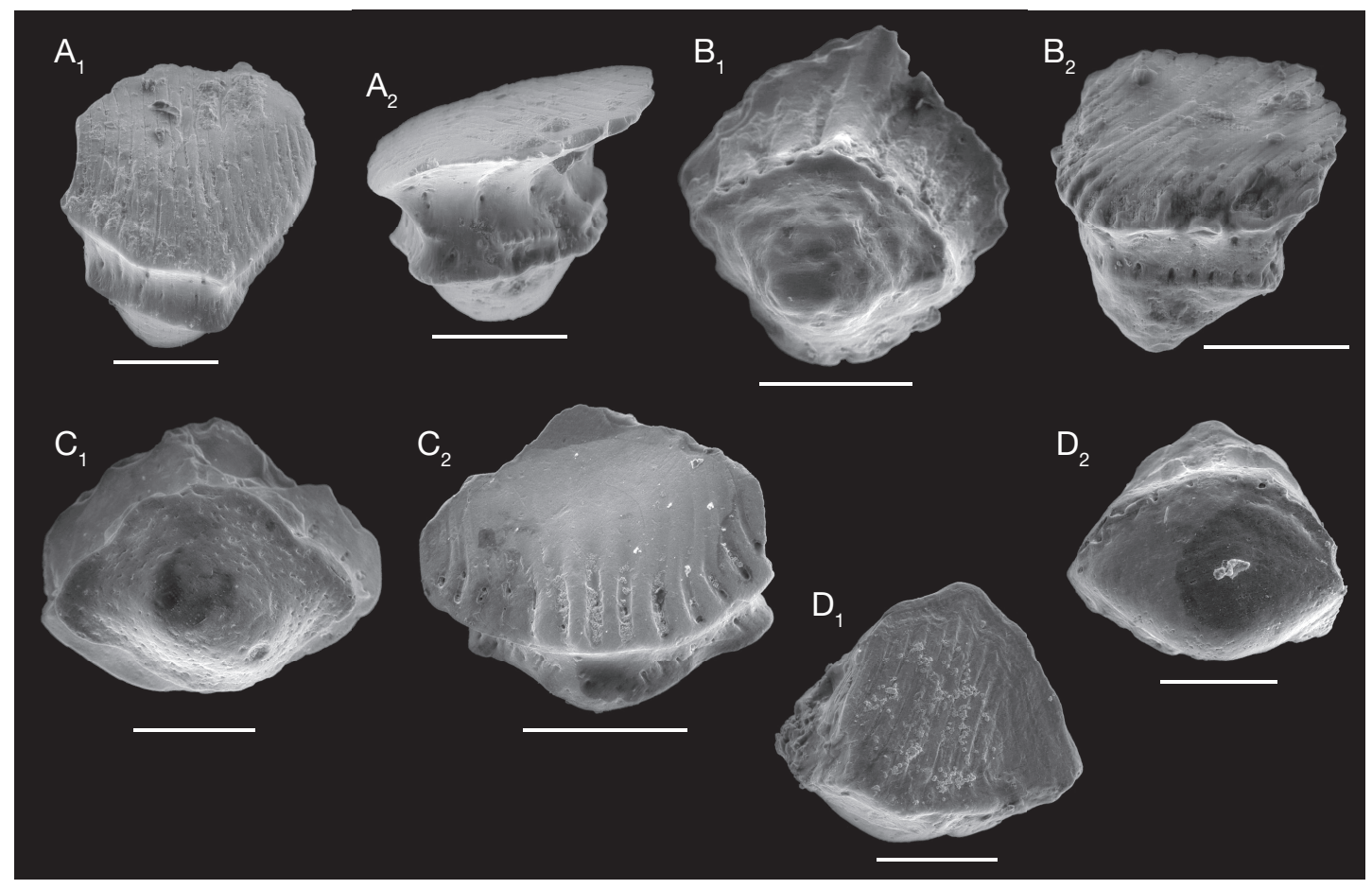

FIG. 8. - Acanthodian scales of Milesacanthus cf. ancestralis from the Emsian (Devonian) of southern Algeria: A, MNHN.F.ALD-36; $\mathbf{A}_{1}$, crown view; $\mathbf{A}_{2}$, lateral view; $\mathbf{B}$, MNHN.F.ALD-37; $\mathbf{B}_{1}$, basal view; $\mathbf{B}_{2}$, front view; C, MNHN.F.ALD-38; $\mathbf{C}_{1}$, basal view; $\mathbf{C}_{2}$, front view; D, MNHN.F.ALD-39; $\mathbf{D}_{1}$, crown view; $\mathbf{D}_{2}$, basal view. Scale bars: A-B, C2, $400 \mu \mathrm{m} ; \mathrm{C} 1, \mathrm{D}, 300 \mu \mathrm{m}$.

have also been assigned to Antarctilamna. The case of Machaeracanthus, considered here as ambiguous, will not be dealt with because it concerns spines and scales. In Spain (Mader 1986; Wang 1993) as in Brittany (Viré-en-Champagne, DG pers. obs.) Leonodus teeth occur with Machaeracanthus scales and/or spines. In the Poyales Escalombreras section (Wang 1993: 100, 141), Leonodus-type teeth and Machaeracanthus-type scales are statistically the most abundant microremains. This observation and the fact that Machaeracanthus scales have a growth style that is at odds with that observed in characteristic acanthodian scales, lead to question the "acanthodian" status of such scales. It might be suggested that Machaeracanthus scales and Leonodus teeth could belong to the same animal. But only the discovery of an articulated (even partially) specimen would test this hypothesis.

The teeth from southern Ahaggar (Fig. 4) represent one of the oldest evidence of multicuspidate teeth.
Derycke (2007) proposed that the asymmetry in the number of cusplets reflects a kind of budding. It is not related to the position in the mouth, which is characterized by a twisted crown or base more than by the number of cusplets, as considered in Thrinacodus St. John \&Worthen, 1875 (Duncan 2003), even though Thrinacoselache Grogan \& Lund, 2008 finally displays a single tooth morphology: asymmetrically curved teeth with twisted lingual bases (Grogan \& Lund 2008: 973).

Regarding the scales (Figs 5-7), their histology is unique, with a network of wide canals opening out anywhere on the scale surface, and a kind of boxin-box pattern with only two growth stages, not continued in the base (Fig. 7A-E, H). The combination of an unusual high neck and short Sharpey's fibers suggests that the scales were inserted deep in the skin and grew inside the skin. Furthermore the morphology, the size but also the density of the cells may depend on the location of the scales on the 
body and their maturation. The type of scale growth does not correspond to any of the types defined by Karatajute-Talimaa (1998: 48). Usually, the growth of the skin is compensated by addition of odontodes in front of, or around their primordium - resulting in a growth in breadth - and/or addition of new larger scales. Here, the scales were growing in height. We are unable to explain this growth or relate it to a particular kind of squamation.

Comparisons were made with other scales, including those of Wetteldorfia, which is considered as an acanthodian (Emsian, Eifel, Vieth-Schreiner 1983; Emsian, Saudi Arabia, Burrow et al. 2006), "Nogueralepis sp." (Emsian, Saudi Arabia, Burrow et al. 2006) and Elegestolepis Karatajute-Talimaa, 1973 (Silurian, Tuva, Karatajute-Talimaa 1973), but the material is considered to be in fact the squamation of Tassiliodus lessardi n. gen., n. sp.

This material raises questions concerning the limits of histological data in the problem of relationships between chondrichthyans and acanthodians: some characters are chondrichthyan ones (pallial dentine, foramina emerging in the neck and in the base), whereas others are more acanthodian-like (box-inbox pattern or "onion-like structure", mesodentine, also foramina in the neck). The relationships between chondrichthyans and acanthodians are already debated and possibly explained by mosaic evolution (Brazeau 2009).

The chondrichthyan material (Figs 4-6) comprises scales and teeth from one small sample (around $5 \times 10$ $\mathrm{cm})$. How can we interpret this assemblage? Does it belong to the same organism? Chondrichthyan teeth (Fig. 4) have been found along with chondrichthyan scales $(93 \%)$ (Figs 5, 6) and acanthodian scales (6\%) (Fig. 8). Furthermore, the presence of tentaculites on the same sample suggests that it rather represents a thanatocoenosis with maybe reworking.

\section{STRATIGRAPHY}

The association with a petalichthyid placoderm and the presence of Arduspirifer, suggests that the sample can be dated as Emsian. This dating is supported by comparisons of the scales with those of Milesacanthus, of "Nogueralepis sp." (Saudi Arabia) and of Wetteldorfia (Eifel \& Saudi Arabia) (Emsian; Vieth-Schreiner 1983; Burrow et al. 2006).

\section{Palaeogeographic InCIDENCE}

Emsian levels in all the Sahara correspond to a transgression (Fabre 1976: 125) and are marine. The early chondrichthyans Pucapumpella and possibly Antarctilamna are known from Gondwana, but Doliodus and Protodus are from Laurussia (Turner \& Miller 2005: 245). The new taxon Tassiliodus n. gen. fills a biogeographic gap (Turner \& Miller 2005: figs 3 ; 6). It is one of the earliest multicuspidate chondrichthyan teeth, and the first evidence for an Emsian chondrichthyan taxon in North-West Gondwana.

The assemblage with Gondwanan affinities (sensu Young 1987 in Forey et al. 1992) found in south Algeria comprises acanthodians, placoderms and chondrichthyans and is comparable to the Saudi Arabian assemblage, sharing an absence of thelodonts, heterostracans, osteostracans and galeaspids (Forey et al. 1992). Some scales confirmed the Gondwanan affinities by comparison to Milesacanthus, Wetteldorfia and the new taxon (previously compared to "Nogueralepis sp.") (Emsian, Saudi Arabia; Burrow et al. 2006).

\section{Acknowledgements}

Thank to the members of Géosystèmes, UMR 8157 CNRS, Lille: P. Recourt for SEM photos, E. Locatelli and A. Blieck for help in the bibliography research and S. Ventalon and E. Try for help in microscopy. Members of the MNHN: O. Catoire (Bibliothèque $\mathrm{MNHN}$ ), for thin sections to $\mathrm{M}$. Lemoine (MNHN, UMR 7207 CNRS, Paris). Thanks to J. Fabre, F. Guillot, P. Legrand for some advice. We are grateful to C. Burrow and to P. Janvier for the improvement of this paper.

\section{REFERENCES}

Anderson M. E., Almon J. E., Evans F. J. \& Long J. A. 1999. - Devonian (Emsian-Eifelian) fish from the Lower Bokkeveld Group (Ceres subgroup), South Africa. Journal of African Earth Science 29 (1): 179-194.

Attar A., Fabre J., JanVier P. \& Lehman J.-P. 1981. Les Vertébrés de la formation de Tiguentourine (Permo-Carbonifère, bassin d'Illizi, Algérie). Bulletin du Muséum national d'Histoire naturelle, $4^{\mathrm{e}}$ sér., sect. C, 4: 301-309. 
BlieCK A. 1982. — Les grandes lignes de la biogéographie des Hétérostracés du Silurien supérieur-Dévonien inférieur dans le domaine Nord-Atlantique. Palaeogeography, Palaeoclimatology, Palaeoecology 38: 283-316.

Blieck A., Goujet D., Janvier P. \& Lelièvre H. 1984. - Microrestes de vertébrés du Siluro-Dévonien d'Algérie, de Turquie et de Thaïlande. Geobios 17: 851-856.

Botella H. 2006. - The oldest fossil evidence of a dental lamina in sharks. Journal of Vertebrate Paleontology 26 (4): 1002-1003.

Botella H., Valenzuela-Rios J. I. \& MartínezPéreZ C. 2009. - Tooth replacement rates in early chondrichthyans: a qualitative approach. Lethaia 42: 365-376.

BRAZEAU M. D. 2009. - The braincase and jaws of a Devonian "acanthodian" and modern gnathostome origins. Nature 457: 305-308.

Burrow C. J., Lelièvre H. \& Janjou D. 2006. — Gnathostome microremains from the Lower Devonian Jawf Formation, Saudi Arabia. Journal of Paleontology 80 (3): 537-560.

Claret J. \& Tempere C. 1965. - Le paléozoïque du bassin du Tamesna (Sud de l'Ahaggar). Zeitschrift der Deutschen Geologischen Gesellschaft 117: 460-468.

DERYCKE C. 2007. - Ontogeny evidences in chondrichthyan teeth, in BLOM H. \& BRAZEAU M. (eds), 40th Anniversary Symposium on Early Vertebrates/Lower Vertebrates. Ichthyoliths Issues Special Publication 10, Uppsala, Sweden, 13-16 August 2007. IGCP 491: Middle Palaeozoic Vertebrate-Biogeography, Palaeogeography, and Climate, abstract: 31,32 .

DerYCKe C. \& GOUJeT D. 2009. - Early Devonian Vertebrate from south Ahaggar (southern Algeria): new observations on the histology of early chondrichthyan scales. Sixty-nine Annual Meeting, Society of Vertebrate Paleontology, University of Bristol, September 23-26 2009. Journal of Vertebrate Paleontology 29 (3): $87 \mathrm{~A}$

DERYCKE \& GOUJET 2010. - Scheme of characters in chondrichthyans (teeth and scales), in THE PALAEONTOLOGICAL ASSOCIATION (ed.), Third International Palaeontological Congress (IPC3). Imperial College and Natural History Museum, London, UK, 28 June-3 July 2010, Abstract: 145.

DERYCKe-KHATIR C. 2005. - Microrestes de vertébrés du Paléozoïque supérieur de la Manche au Rhin. Publication de la Société géologique du Nord 33: 1-363.

DunCAN M. 2003. - Early Carboniferous chondrichthyan Thrinacodus from Ireland, and a reconstruction of jaws apparatus. Acta Palaeontologica Polonica 48 (1): 113-122.

FABRE J. 1976. - Introduction à la géologie du Sahara Algérien. Société nationale d'Édition et de Diffusion, Alger, $422 \mathrm{p}$.
FABRE J. 2005. - Géologie du Sahara occidental et central. Tervuren African Geoscience Collection, 108, $572 \mathrm{p}$.

Forey P. L., Young V. T. \& McClure H. A. 1992. Lower Devonian fishes from Saudi Arabia. Bulletin of the British Museum (Natural History) (Geology) 48 (2): 25-43.

Gagnier P.-Y., Turner S., Friman L., SuARes-Riglos M. \& Janvier P. 1988. - The Devonian vertebrate and mollusc fauna from Seripona (Dept. of Chuquisaca, Bolivia). Neues Jahrbuch für Geologie und Paläontologie 176 (2): 269-297.

GiNTER M. 2004. - Devonian sharks and the origin of Xenacanthiformes, in ARRATIA G., Wilson M. V. H. \& Cloutier R. (eds), Recent Advances in the Origin and Early Radiation of Vertebrates. Verlag Friedrich Pfeil, München: 473-486.

Ginter M., Hairapetian V. \& Klug C. 2002. Famennian chondrichthyans from the shelves of North Gondwana. Acta Geologica Polonica 52 (2): 169-215.

Grogan E. D. \& Lund R. 2008. - A basal Elasmobranch, Thrinacoselache gracia n. gen. \& sp. (Thrinacodontidae, new family) from the Bear Gulch Limestone, Serpukhovian of Montana, USA. Journal of Vertebrate Paleontology 28 (4): 970-988.

Janvier P. \& Suarez-Riglos M. 1986. — The Silurian and Devonian vertebrates of Bolivia. Bulletin de l'Institut français d'Études andines 15 (3-4): 73-114.

JohANSON Z. \& SMITH M. M. 2003. — Placoderm fishes, pharyngeal denticles, and the vertebrate dentition. Journal of Morphology 257: 289-307.

Karatajute-TAlimaA V. 1973. - Elegestolepis grossi gen. et sp. nov., ein neuer Typ der Placoidschuppe aus dem oberen Silur der Tuwa. Palaeontographica Abt. A, 143 (1-6): 35-50.

Karatajute-TalimaA V. 1998. — Determination methods for the exoskeletal remains of early vertebrates. Mitteilungen aus dem Museum für Naturkunde in Berlin, Geowissenschaftliche Reihe 1: 21-52.

LeHMan J. P. 1951. — Arthrodires Brachythoraci Dinichthydae Dévonien supérieur Tafilalet. Comptes Rendus de l'Académie des Sciences 232: 2237-2239.

LEHMAN J. P. 1952a. - Notes paléoichthyologiques. Annales de Paléontologie 38: 59-67.

Lehman J. P. 1952b. - Les Arthrodires du Maroc méridional. Comptes Rendus de l'Académie des Sciences 234: 2631-2633.

LEHMAN J. P. 1964. - À propos de quelques Arthrodires et Ichthyodorulites Sahariens. Mémoire IFAN 68: 193-200.

LelièVre H. 1988. - Nouveau matériel d'Antineosteus lehmani Lelièvre, 1984 (Placoderme, Brachythoraci) et d'Acanthodiens du Dévonien inférieur (Emsien) d'Algérie. Bulletin du Muséum national d'Histoire naturelle, 4e série, sect. A 10: 287-302. 
Lelièvre H., Janvier P. \& Blieck A. 1993. - Silurian-Devonian vertebrate biostratigraphy of Western Gondwana and related terranes (South America, Africa, Armorica-Bohemia, Middle East), in Long J. A. (ed.), Palaeozoic Vertebrate Biostratigraphy and Biogeography 7: 139-173.

LESSARD L. 1961. — Les séries primaires des Tassilis Ouan-Ahaggar au Sud du Hoggar entre l'Aïr et l'Adrar des Iforas (Sahara méridional). Bulletin de la Société géologique de France, 7e série, III (5): 501-513.

LonG J. A. \& Young G. C. 1995. - Sharks from the Middle-Late Devonian Aztec Siltstone, southern Victoria Land, Antarctica. Records of the Western Australian Museum 17: 287-308.

Mader H. 1986. - Schuppen und Zähne von Acanthodiern und Elasmobranchiern aus dem Unter-Devon Spaniens (Pisces). Göttinger Arbeiten zur Geologie und Paläontologie 28: 1-59.

MaISEY J. G. 1981. - Studies on the Paleozoic selachian genus Ctenacanthus Agassiz. $\mathrm{N}^{\circ} 1$. Historical review and revised diagnosis of Ctenacanthus, with a list of referred taxa. American Museum Novitates 2718: 1-22.

MAISEY J. G. 2001. - A primitive chondrichthyan braincase from the Middle Devonian of Bolivia, in AHLBERG P. E. (ed.), Major Events in Early Vertebrate Evolution. Systematic association Special Volume, Taylor \& Francis, London-New York, Series 61: 263-288.

MAISEY J. G. 2004. - Endocranial morphology in fossil and recent chondrichthyans, in ARRATIA G., WILSON M. V. H. \& Cloutier R. (eds), Recent Advances in the Origin and Early Radiation of Vertebrates. Verlag Friedrich Pfeil, München, Germany, 139-170.

Maisey J. G. \& ANDERSON M. E. 2001. - A primitive chondrichthyan braincase from the Early Devonian of South Africa. Journal of Vertebrate Paleontology 21: 702-713.

Maisey J. G. \& Melo J. H. G. 2005. - Some Middle Devonian (Eifelian-Givetian) fossil fish remains from the Pimenteira Formation of the Parnaiba basin, northeast Brazil. Arquivos do Museu Nacional, Rio de Janeiro, 63 (3): 495-505.

Miller R. F., Cloutier R. \& Turner S. 2003. - The oldest articulated chondrichthyan from the Early Devonian period. Nature 425: 501-504.
Nedjari A., Ait Ouali R., Chikhi-Aouimeur F. \& Bitam L. 2007. — Le Bassin de l'Ougarta au Paléozoïque: une mobilité permanente. Livret guide, 2 ème Séminaire National de Stratigraphie, Béni-Abbès, 7-10 décembre 2003, Mémoires du Service Géologique National, Alger, 96 p.

ØRVIG T. 1967. - Phylogeny of tooth tissues: evolution of some calcified tissues in early vertebrates, in Miles A. (ed.), Structural and chemical organization of teeth 1. Academic Press, New York: 45-110.

RADINSKY L. 1961. - Tooth histology as a taxonomic criterion for cartilaginous fishes. Journal of Morphology 109 (1): 73-92.

Smith M. M. \& Johanson Z. 2003. - Separate evolutionary origins of teeth from evidence in fossil jawed vertebrates. Science 299: 1235, 1236.

TURNER S. 2004. - Early vertebrates: analysis from microfossil evidence, in ArRatia G., Wilson M. V. H. \& Cloutier R. (eds), Recent Advances in the Origin and Early Radiation of Vertebrates. Verlag Friedrich Pfeil, München, Germany: 67-94.

Turner S. \& Miller R. F. 2005. - New ideas about old sharks. American Scientist 93: 244-252.

Turner S. \& Miller R. F. 2008. - Protodus jexi Woodward, 1892 (Chondrichthyes), from the Lower Devonian Campbellton Formation, New Brunswick, Canada. Acta Geologica Polonica 58 (2): 133-145.

Vieth-Schreiner J. 1983. - Fisch-Schuppen und -Zähne aus der Eifeler Kalkmulden-Zone (Emsium, Eifelium). Senckenbergiana lethaea 64 (2): 129-177.

WANG R. 1993. - Taxonomie, Palökologie und Biostratigraphie der Mikroichthyolithen aus dem Unterdevon Keltiberiens, Spanien. Courier Forschunginstitut Seckenberg 161: 1-208.

YounG G. C. 1982. - Devonian sharks from southeastern Australia and Antarctica. Palaeontology 25 (4): 817-843.

Young G. 1987. - Devonian Palaeontological data and the Armorica problem. Palaeogeography, Palaeoclimatology, Palaeoecology 60: 283-304.

YounG G. C. \& Burrow C. J. 2004. — Diplacanthid acanthodians from the Aztec Siltstone (late Middle Devonian) of southern Victoria Land, Antarctica. Fossils and Strata 50: 23-43. 